The Third Pole: Journal of Geography

Vol. 17: 51-58, 2017

Department of Geography Education, Central Department of Education, T.U., Kathmandu, Nepal

\title{
AVAILABILITY AND UTILIZATION OF INSTRUCTIONAL MATERIALS IN TEACHING GEOGRAPHY IN SECONDARY SCHOOLS
}

\author{
Keshav Raj Dhakal ${ }^{1}$
}

\begin{abstract}
This study examines the availability and utilization of instructional materials in geography teaching in community secondary schools in Kathmandu district. There are altogether sixteen community secondary schools offering geography as an optional subject. Out of sixteen secondary schools offering geography as an optional subject eight schools are selected for the study on the basis of random sampling. The sample for this study comprised of one hundred seventy four students from selected secondary schools. The survey and observation are used for primary data collection. The data are analyzed using percentage. The results reveal that printed and graphic instructional materials for teaching geography in secondary schools are available and their utilization is of high extent while audio, visual and audio-visual instructional materials for teaching geography are not available sufficiently and they are used less often in the classrooms for teaching geography. The local materials are rarely utilized in schools by the teachers. All stakeholders in education must rise to the challenges of making instructional materials are available and utilized in secondary schools.
\end{abstract}

Keywords: Instructional materials, graphic, audio, visual, audio visual, local materials

\section{Introduction}

Geography is an old discipline on the basis of human knowledge about his environment, the world and his relationship with the environment. The history of geography dates back to the Vedic Era in the oriental mythology. The word geography has been used since the

1 Mr. Dhakal is an Associate Professor of Geography Education, Central Department of Education,T.U.Kirtipur,Email: dhakalkeshav@hotmail.com 
time of Eratosthenes. In the western world the scientific study began only during the nineteenth century after philosophers like Kant, Humboldt, Ritter, Peschel and Ratzel defined the scope and content of the subject (Hartshorn, 1962 cited in Amatya, 1974). At present, geography is commonly referred to as the study of the environment and man's changing relationship with it. The horizon of geography teaching is widening. Geography is changing its structure descriptive to dynamic (Pandey, 1998). Today the focus of geography is generally conceded to be on spatial interactions of human activity within a spatial framework.

Geography provides opportunities to develop key knowledge, skills, and values that enable students to become responsible citizens. The full and healthy geography education provides a connection to other people in the world, relationship with the environment, perceive the skills, knowledge and concepts and fundamental that help human understand (Tomal, 2004). The study of geography is divided into location, place, human/environment interaction, movement, and region which offer a mode of reasoning about the world. These themes can assist in studying every geographic issue locally, nationally and globally (Boehm, 2000).

Being diverse topography and other physical environment, the necessity of geography education is very important in Nepal. Geography is being included as a part of social studies in the secondary level. In secondary level there is also a provision of selection of geography as an optional subject in present school curriculum. Over the years, geography has been assumed to play an important role in school programs. Okobia (2011) summarized the importance of using instructional materials in the classroom to include: a. making the subject matter more real. b. explicating difficult concepts. c. making the learner experience what is being learnt. $d$. helping to fire the imagination of the learners. e. preventing misconceptions. f. making learning interesting amongst others.

Instructional materials greatly influence education quality and standards and they affect the teaching and learning process. Instructional materials and learning resources are associated with objects, persons or other aspects of the environment which can be used to impact, or help in any learning activity. Instructional materials are intermediate or mediating materials used in instruction or teaching learners so as to make the learning objectives clearer and teaching easier. A careful explanation of a subject may not absolutely lead to a better understanding of that particular subject by adults, whereas, 
Keshav Raj Dhakal / Availability and Utilization of Instructional Materials in Teaching ...

the use of teaching aids or instructional materials provides clarity on issues that are of learning interest to the adults (Knowles, 1996).

Instructional materials in teaching generally make the teaching process easier in geography teaching. For the teaching of geography to be effective, it is necessary for teachers to make and use of different types of instructional materials. Geography focuses on disciplinary change and paradigm shift which makes the use of instructional materials important in teaching and learning. Geography as one of the subjects at the secondary schools will be better facilitated when suitable and relevant instructional materials are prepared and utilized during its teaching and learning (Dhakal, 2014).

For teaching and learning activities to be effective and purposeful, the teacher has to make and use of the appropriate instructional materials. The teacher must know the instructional materials that are available for teaching geography and be able to utilize them for achieving the educational objectives. This implies that the use of instructional materials is inevitable if effective teaching and learning must be achieved. It is said that one picture is equal to one thousand words. This agrees with the Chinese proverb that state: The thing which I hear, I may forget, the thing which I see, I may remember, the thing which I do, I cannot forget. When instructional materials are properly used, they help to consolidate learning in the learner's mind. The use of instructional materials therefore, becomes very crucial in improving the overall quality of the learning experiences of students. Therefore, the selection and use of instructional materials in teaching and learning geography are determined by the particular aspect of geography that the teacher intends to teach at a particular point in time. This study throws light to the availability of instructional materials and examines the extent of utilization of the available instructional materials in teaching and learning of geography.

\section{Methods and Materials}

The schools offering geography in Kathmandu district as an optional subject were identified. Out of sixteen community schools offering geography as an optional subject eight schools were selected for the study on the basis of random sampling. The population consists of secondary school level students. Among the students, twenty percent students in selected schools were sampled by lottery method. The sample for this study comprised of one hundred seventy four students from selected secondary schools. The primary data were collected through a questionnaire and observation. The major tool of data collection was structured questionnaire and class observation sheet. The secondary data were acquired from the review of the published and unpublished 
and electronic materials. After collecting data, the data were tabulated with coding and tables were constructed with percentage figures. The simple statistical tools have been used to the data analysis.

\section{Results and Discussion}

Observation and survey on availability and utilization of instructional materials in teaching geography in secondary schools showed that the various instructional materials included printed instructional materials, graphic instructional material, audio materials, visual materials and audio visual materials are used as teaching materials. Planning the instructional materials on the part of the facilitators is very important in attempt to get good results as the outcome of the learners. The results of the study were obtained from the data collected and analyzed which are shown in the following tables.

\section{Availability of instructional materials}

The extent of availability of instructional materials for teaching and learning of geography in secondary schools affect quality of education. There has been an increasing concern for effectiveness and efficiency in the teaching and learning process in recent times. The influence of instructional materials in promoting student's academic performance and teaching and learning in educational development is indisputable. To find out the availability of materials used for teaching and learning geography, the respondents were asked and observed to state the geography instructional materials in their schools is presented in Table 1.

\section{Table 1: Availability of instructional materials in schools}

\begin{tabular}{|c|c|c|c|c|}
\hline Types of instructional materials & NYR & Percent & NNR & Percent \\
\hline $\begin{array}{l}\text { Printed Materials (reference book, magazine, } \\
\text { journal, newspaper, teachers guide, dictionary) }\end{array}$ & 114 & 65.51 & 60 & 34.49 \\
\hline $\begin{array}{l}\text { Graphic Materials (chart, graph, map, atlas, } \\
\text { globe, poster, diagram) }\end{array}$ & 136 & 78.16 & 38 & 21.84 \\
\hline Audio Materials (tape, cassette, radio) & 70 & 40.23 & 104 & 59.77 \\
\hline $\begin{array}{l}\text { Visual Materials (photo, slide, filmstrip, } \\
\text { overhead projector) }\end{array}$ & 64 & 36.78 & 110 & 63.22 \\
\hline $\begin{array}{l}\text { Audio Visual Materials (motion picture, } \\
\text { television, computer, video) }\end{array}$ & 46 & 26.44 & 128 & 73.56 \\
\hline
\end{tabular}

Source: Field Survey, 2014.

Note: $\mathrm{NYR}=$ Number of yes response, $\mathrm{NNR}=$ Number of no Response 
Keshav Raj Dhakal / Availability and Utilization of Instructional Materials in Teaching ...

The figure in the first item, $65.51 \%$ of the respondents responded that printed materials were available in their schools while $34.49 \%$ respondents responded contrary. This implies that printed materials (reference book, magazine, journal, newspaper, teachers guide, dictionary etc.) are mostly available in their school. Text books are not included in this study. Item 2 shows that $78.16 \%$ respondents said that graphic materials were available in their school while $21.84 \%$ respondents said that these materials were not available in their schools. This indicated that graphic materials (chart, graph, map, atlas, globe, poster, diagram etc.) are available in the schools. Item 3 in table reveals that $40.23 \%$ respondents responded that audio materials were available while $59.77 \%$ said that these materials were not available in their schools. This indicates unavailability of audio materials (tape, cassette, radio) in the schools.

Items 4 shows that visual materials (photo, slide, filmstrip, overhead projector) are not sufficiently available for using in schools. Only $36.78 \%$ respondents said that they have visual materials in their schools. $63.22 \%$ respondents responded that they don't have visual materials in their schools. In the last item $26.44 \%$ respondents maintained that audio visual materials were available and $73.56 \%$ respondents responded that they were not available in their school. This figure indicates that audio visual materials (motion picture, television, computer, video etc.) are not available in secondary schools.

\section{Utilization of instructional materials}

The use of instructional materials gives the learner opportunity to touch, smell or taste objects in the teaching and learning process. Knowledge and skill can be passed into students with different types of relevant instructional materials. The use of instructional materials becomes very crucial in improving the overall quality of the learning experiences of school level students. The students were asked to state the extent to which their teachers used teaching and learning materials in teaching and learning geography other than textbooks. 
The Third Pole: Journal of Geography, Volume 17, 2017

Table 2: Utilization of instructional materials in schools

\begin{tabular}{lllll}
\hline Instructional materials & $\begin{array}{c}\text { Frequently } \\
(\%)\end{array}$ & $\begin{array}{c}\text { Sometimes } \\
(\%)\end{array}$ & $\begin{array}{l}\text { Rarely } \\
(\%)\end{array}$ & Never (\%) \\
\hline $\begin{array}{l}\text { Printed Materials (reference book, } \\
\text { magazine, journal, newspaper, }\end{array}$ & 51.72 & 25.29 & 5.75 \\
teachers guide, dictionary) & & & \\
$\begin{array}{l}\text { Graphic Materials (chart, graph, } \\
\text { map, atlas, globe, poster, diagram) }\end{array}$ & 57.47 & 19.54 & 3.45 \\
$\begin{array}{l}\text { Audio Materials (tape, cassette, } \\
\text { radio) }\end{array}$ & 34.00 & 57.47 & 8.04 \\
$\begin{array}{l}\text { Visual Materials (photo, slide, } 0.00 \\
\text { filmstrip, overhead projector) }\end{array}$ & 28.74 & 57.47 & 13.80 \\
$\begin{array}{l}\text { Audio Visual Materials (motion } \\
\text { picture, television, computer, } \\
\text { video) }\end{array}$ & 11.50 & 45.97 & 42.53 \\
\hline
\end{tabular}

Source:Field Survey, 2014.

Data on the use of printed materials (reference book, magazine, journal, newspaper, teachers guide, dictionary etc.) shows that $17.24 \%$ of the respondents responded on frequently used of printed materials in teaching geography in secondary schools while $51.72 \%$ indicated that the teachers sometimes used such materials, a quarter respondent said the teachers rarely used materials and 5.75\% respondents said that they were not used by the teacher in the classroom in item 1 . This means that printed materials are utilized in schools by geography teachers. Items 2 shows that $57.47 \%$ of the respondents maintained that graphic materials were sometimes used in teaching geography class room, $19.54 \%$ of the respondents said the teachers frequently used materials or rarely used them and $3.45 \%$ said that they were not used by the teacher in the classroom. This indicates that graphic materials (chart, graph, map, atlas, globe, poster, diagram etc.) are utilized in schools by geography teachers.

In case of audio material none of the respondents agreed to its frequent use. $34.48 \%$ of the respondents maintained teachers sometimes used materials, $57.47 \%$ of the respondents said that the teachers rarely used them and $8.04 \%$ respondents said that they were not used by the teacher at all in the classroom. This means that audio materials are not frequently utilized in school by the teachers. Data on item 4 reveal that none of the respondents agreed to frequent use of visual materials, only $28.74 \%$ said that these materials were sometimes used, $57.47 \%$ maintained teachers rarely use materials 
and $13.80 \%$ said that they were not used by the teacher in teaching geography in the classroom. $92 \%$ of the respondents were of the view that they were never used in the classroom. Item 5 shows that none of the respondents agreed to its frequent use, $11.50 \%$ of the respondents maintained that audio visual materials were sometimes used, $45.97 \%$ said that they are rarely used materials in teaching geography classroom and $42.53 \%$ said that they are not used by the teacher in the classroom. This implies that visual and audio visual materials are not utilized for the teaching of geography in secondary schools. Local materials (mud floor, stones, bricks, stick, culture and tradition etc.) are not utilized in secondary schools by the teachers in geography teaching.

\section{Conclusion}

Geography is a discipline that examines the relationships between people and earth, what people are doing as a result of these relationships and what they can do. Geographic concepts should be taught through the use of different instructional materials. Based on the results of this study, apart from printed material and graphic materials, most school lacks other valuable instructional materials for teaching and learning geography in the classroom. The researcher concluded that the issue of availability and utilization of instructional materials in teaching geography has not been satisfactory in secondary school. The needed improvement in the quality of teaching and learning in secondary schools can be achieved greatly, if teaching strategy is enhanced through the utilization of more and more instructional materials in geography teaching. Local materials are not utilized in secondary schools by teachers. Geography teachers should improvise some of the instructional materials locally. If teachers are facilitated and provided some support, the concept of locally available teaching materials in geography, could be effective and productive. The school authority should provide support to collect and use of local instructional materials that are lacking in the school. The federal, state and local governments should provide instructional materials to the school which cannot be afforded by the school, itself.

\section{References}

Amatya, S. L. (1974). Geography in Nepal. In Prayag Raj Sharma (Ed), Social Science in Nepal.Kathmandu.Institute of Nepal and Asian Studies.Pp.1-17.

Boehm, R. (2000). Glencoe World Geography: A physical and cultural approach. New York: MacGraw-Hill 
The Third Pole: Journal of Geography, Volume 17, 2017

Dhakal K. R. (2014). High School Students and Teachers Attitude towards Geography Education: A Study of Kathmandu District, Research Report Submitted to the UGC Nepal, Bhaktapur.

Knowles, M. (1996).Andragogy: An emerging technology for adult learning. London: Kongan Page Ltd.

Okobia E. O. (2011). Availability and teachers' use of instructional materials and resources in

the implementation of social studies in junior secondary schools in edo state, Nigeria.

Review of European Studies; Vol. 3, Number 3; December 2011. Retrieved from www. ccsenet.org/res.

Panday, R. K.(1998) Pioneers of Nepalese Geography: Geography and Geographers in Nepal. Kathmandu: Center for Nepalese Geography. Pp.138

Tomal, N. (2010). High School Students Attitude towards Geography and the questions that they wonder about it. Retrieved June 12, 2016 from http// www. academicjournal .org/sre 